\title{
Hydrologic balance estimation using GIS in Korinthia prefecture, Greece
}

\author{
K. Voudouris ${ }^{1}$, Th. Mavrommatis ${ }^{1}$, and A. Antonakos ${ }^{2}$ \\ ${ }^{1}$ Aristotle University, Dept. of Geology, Thessaloniki, Greece \\ ${ }^{2}$ University of Patras, Dept. of Geology, Greece
}

Received: 26 March 2007 - Revised: 5 April 2007 - Accepted: 14 April 2007 - Published: 19 September 2007

\begin{abstract}
The main objective of this work is to determine the parameters of hydrological balance for several basins in the prefecture of Korinthia (SE Greece), using hydrometeorological data and geographic information systems (GIS) technology. Multiple linear regression and GIS were used to estimate the spatial distribution of rainfall. The largest precipitation amounts occur in the SW part of the region and decrease towards the eastern and northern coastal parts. The long term mean annual rainfall is $1.39 \times 10^{9} \mathrm{~m}^{3}$. Based on the Thornthwaite method, infiltration and streamflow were estimated to be $0.29 \times 10^{9} \mathrm{~m}^{3} / \mathrm{yr}$ and $0.38 \times 10^{9} \mathrm{~m}^{3} / \mathrm{yr}$, respectively. The unequal distribution of rainfall results in water surplus in the western part of Korinthia prefecture and water deficit in the eastern. We conclude that he estimation of hydrologic balance is a useful tool in order to establish sustainable water resources management in each hydrological basin.
\end{abstract}

\section{Introduction}

The prefecture of Korinthia is located in the NE part of Peloponnesus in southern Greece, covering a total area of $2264 \mathrm{~km}^{2}$ (Fig. 1).

Socioeconomic stability of the studied area is based on water resources availability which ensures adequate agricultural production and tourism development. The prefecture of Korinthia is characterised by non homogeneous distribution of rainfalls and water resources. Unfavourable climatic conditions combined with continuous population growth, rapid urbanization and intensive agricultural development have increased the demand for water. The major water use in Korinthia is irrigation for agriculture (86\% of the total consumption). Water needs are mainly covered by groundwater abstracted by numerous wells and boreholes. The intense groundwater exploitation has led to aquifer depletion, water level decline and quality deterioration, which have negative consequences in the socioeconomic development of the area (Panagopoulos et al., 2002; Voudouris, 2006). Thus, the knowledge of hydrologic parameters is a useful tool for rational water resources management in regional scale.

Geographic Information System (GIS) technology has been increasingly used in supporting water resources management applications. Many researchers have estimated the

Correspondence to: K. Voudouris

(kvoudour@geo.auth.gr)

Published by Copernicus Publications. parameters of the hydrological balance with the use of rasterbased GIS (Maidment, 1993; Ross and Tara, 1993; Naoum and Tsanis, 2004).

The objective of this work is to estimate the parameters of hydrological balance for several basins in the prefecture of Korinhtia, using hydrometeorological data, geological maps and GIS technology.

\section{General features}

\subsection{Physiography}

The Korinthia prefecture is surrounded by sea (Korinthiakos and Saronikos gulf) and mountains: Killini or Ziria (2376 m), Chelmos (2109 m), Gerania (1350 m), Onia (570 m). Lowlands, semi-mountainous and mountainous areas occupy $18.3,22.5$ and $59.2 \%$, respectively, of the total land. Currently $30.5 \%$ of land is occupied by forest, $26 \%$ by grassland and $31.6 \mathrm{~km}^{2}(1.3 \%)$ by water. More than $35 \%$ of the total area is used for agriculture.

Using ArcView GIS, the hydrological basins were delineated. The study area consists of 23 drainage basins (Fig. 3). The largest basin is the Asopos river basin, covering an area of $257 \mathrm{~km}^{2}$. There is also a shallow mountain lake (Stimfalia) covering an area varying from 350 hectares (in dry periods) to 770 (in wet periods). 


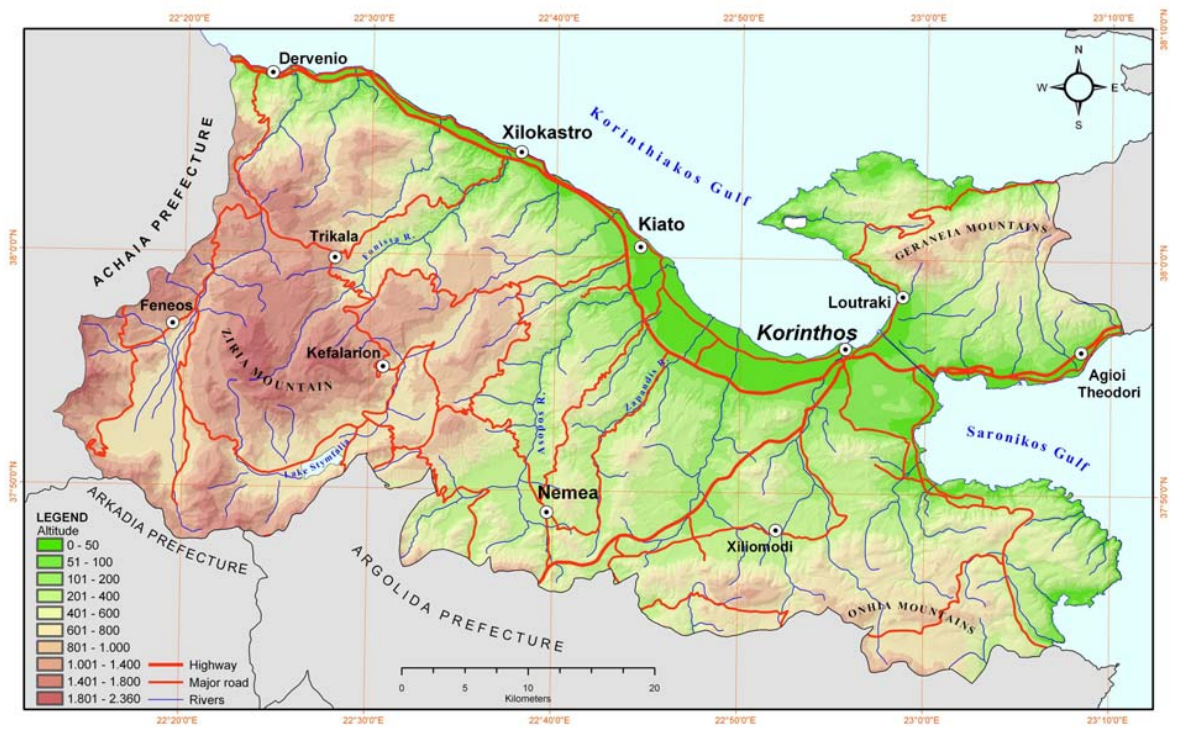

Figure 1. Topographic map of Korinthia prefecture.

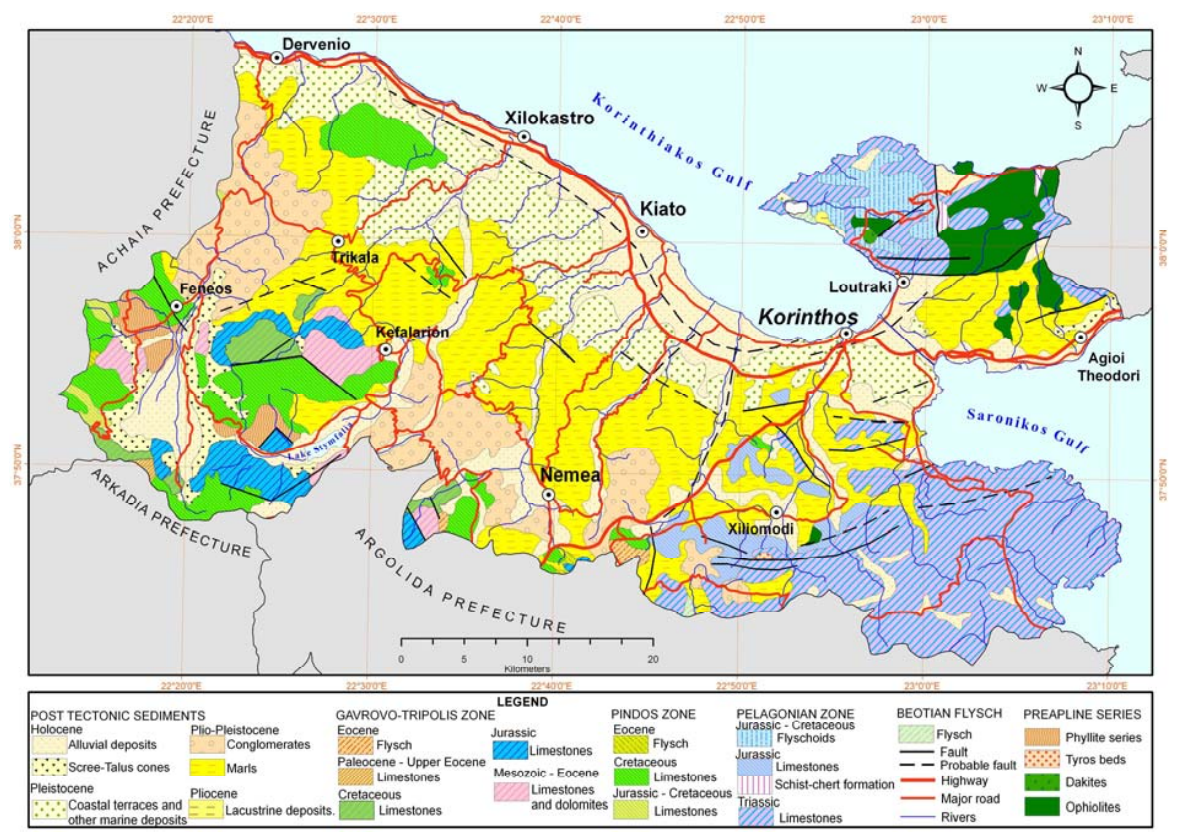

Figure 2. Geological map of Korinthia.

\subsection{Geology}

The study area is characterized by a complex geological structure (Fig. 2). The following geological formations can be identified in the area (Rockel and Hotzl, 1986; Nikolaou et al., 1997): Quaternary deposits consisting of alternations of coastal (sands) and fine, coarse or mixed facies formations; Plio-pleistocene deposits consisting of fine, coarse or mixed facies sediments (marls, sandstones, conglomerates, limestones etc), which cover to a high extent the northern and central part of the study area; Baserock formations (flysch, limestones-dolomites, semi-metamorphic formations), mainly cover the southwestern part of the prefecture. Carbonate formations cover $26 \%$ of the total area and are occupy mainly the south-western and eastern part of the prefecture. The study area is covered by integrated geological maps at a scale of 1:50000 (Institute of Geological and Mineral Exploitation). 


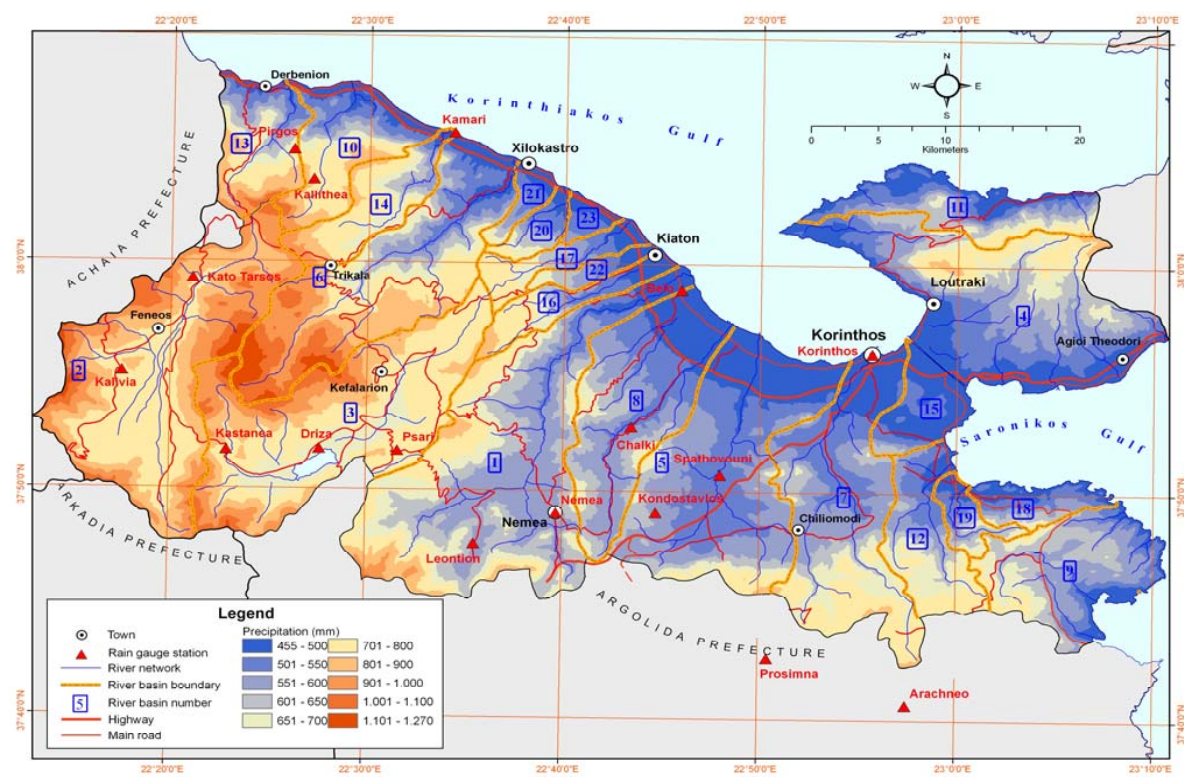

Figure 3. Distribution of annual rainfall (mm) based on Eq. (3).

\subsection{Climate}

According to the Thornthwaite classification system, the studied area has a semiarid climate in lowlands and a typical Mediterranean climate in highlands, with four distinct seasons. $85 \%$ of total precipitation generally occurs in the wet period, which normally extends from late October through May, with sparse storm events during the summer months. The mean annual air temperature at sea level is $17.5^{\circ} \mathrm{C}$ and decreases by $0.59^{\circ} \mathrm{C}$ per $100 \mathrm{~m}$ of ground elevation. January is the coldest month and July is the hottest. Summer temperatures often exceed $35^{\circ} \mathrm{C}$. Relative humidity extremes, on monthly basis, range from $48-52 \%$ in July to $73-76 \%$ in December; on annual basis relative humidity ranges from $62.8 \%$ to $68.8 \%$.

\section{Hydrological balance components}

The hydrologic balance of one basin is given by the equation:

$$
P=R+E+I+d w+d q
$$

where: $P=$ rainfall, $R=$ the streamflow, $E=$ evapotranspiration, $I=$ infiltration, $d w=$ the variation of the quantity of groundwater reserves, and $d q=$ the result of human intervention.

Considering the factors $\mathrm{dw}$ and $\mathrm{dq}$ as negligible, the Eq. (1) becomes:

$P=R+E+I$

Using hydrometeorological data, geological maps, multiple regression method and GIS technology the hydrological balance components were estimated for each watershed of Korinthia prefecture, as follows.

\subsection{Precipitation}

The effects of geographical parameters on the rainfall distribution in Korinthia have been extensively studied and reported (Voudouris et al., 2002; Voudouris and Antonakos, 2003). The distribution of the mean annual rainfall is governed by the following rules:

- Mean annual rainfall decreases with distance from the sea

- Mean annual rainfall increases with elevation above the sea level (a.s.l).

For this investigation, monthly rainfall data were collected from 15 gauging stations of Korinthia's prefecture and 2 from the prefecture of Argolida (Prosimni, Arachneo) for the period 1970-1999 (Table 1, Fig. 2). The gauges are located at elevation ranged from 10 a.s.l. (Kamari station) to $1030 \mathrm{~m}$ a.s.l. (Tarsos station). The completion of missing monthly observations, which were randomly distributed throughout the operational period of few stations only, has been realized by the normal-ratio method (Linsley et al., 1988). No problem was identified in the homogeneity of rainfall data when the method of double mass curve and the criterion of Bartlett (Mitchell et al., 1966; Macheras and Kolyva-Machera, 1990) were applied.

Rainfall data analysis showed rainfall depth decreasing in West-to-East and North-to-South directions. The largest precipitation ammonuts, on annual basis, occur in the southwestern part of the study area: Kastania $(912 \mathrm{~mm})$, Kalivia $(891 \mathrm{~mm})$, Tarsos $(776 \mathrm{~mm})$ with the highest ground elevation. On the contrary, the rainfall depths are comparatively 
Table 1. Rainfall data in $\mathrm{mm}$ of Korinthia prefecture. The location of rain gauge stations is shown in Fig. 3.

\begin{tabular}{clcccccc}
\hline & Rain gauge Station & Altitude $(\mathrm{m})$ & Longitude & Latitude & Yearly Mean & Standard deviation & Min-Max Values \\
\hline 1 & Velo & 20 & $22^{\circ} 45^{\prime}$ & $37^{\circ} 58^{\prime}$ & 473.2 & 116.1 & $308-714$ \\
2 & Korinthos & 15 & $22^{\circ} 27^{\prime}$ & $37^{\circ} 56^{\prime}$ & 409.0 & 88.3 & $195-707$ \\
3 & Kamari & 10 & $22^{\circ} 34^{\prime}$ & $38^{\circ} 06^{\prime}$ & 474.6 & 97.5 & $277-609$ \\
4 & Leontio & 320 & $22^{\circ} 36^{\prime}$ & $37^{\circ} 48^{\prime}$ & 682.8 & 226.5 & $371-1080$ \\
5 & Nemea & 289 & $22^{\circ} 40^{\prime}$ & $37^{\circ} 50^{\prime}$ & 612.9 & 150.2 & $323-892$ \\
6 & Pirgos & 645 & $22^{\circ} 26^{\prime}$ & $38^{\circ} 05^{\prime}$ & 682.6 & 157.4 & $415-1035$ \\
7 & Kallithea & 120 & $22^{\circ} 27^{\prime}$ & $38^{\circ} 07^{\prime}$ & 550.3 & 129.7 & $298-835$ \\
8 & Ancient Kleones & 300 & $22^{\circ} 45^{\prime}$ & $37^{\circ} 50^{\prime}$ & 561.3 & 146.3 & $331-757$ \\
9 & Kastania & 989 & $22^{\circ} 23^{\prime}$ & $37^{\circ} 52^{\prime}$ & 912.0 & 233.1 & $558-1340$ \\
10 & Driza & 631 & $22^{\circ} 28^{\prime}$ & $37^{\circ} 52^{\prime}$ & 663.3 & 192.2 & $384-1057$ \\
11 & Psari & 821 & $22^{\circ} 32^{\prime}$ & $37^{\circ} 52^{\prime}$ & 685.8 & 155.4 & $396-1007$ \\
12 & Spathovouni & 140 & $22^{\circ} 48^{\prime}$ & $37^{\circ} 51^{\prime}$ & 429.6 & 114.5 & $292-541$ \\
13 & Kalivia & 850 & $22^{\circ} 18^{\prime}$ & $37^{\circ} 55^{\prime}$ & 890.7 & 264.0 & $504-1294$ \\
14 & Chalki & 250 & $22^{\circ} 44^{\prime}$ & $37^{\circ} 53^{\prime}$ & 552.6 & 128.2 & $314-716$ \\
15 & Tarsos & 1.030 & $22^{\circ} 21^{\prime}$ & $38^{\circ} 00^{\prime}$ & 776.3 & 174.6 & $536-1083$ \\
16 & Arachneo & 620 & $22^{\circ} 58^{\prime}$ & $37^{\circ} 41^{\prime}$ & 659.6 & 136.8 & $360-1030$ \\
17 & Prosimni & 240 & $22^{\circ} 50^{\prime}$ & $37^{\circ} 43^{\prime}$ & 529.1 & 117.9 & $326-920$ \\
\hline
\end{tabular}

small in the eastern coastal part of Korinthia: Korinthos $(409 \mathrm{~mm})$, Spathovouni $(429 \mathrm{~mm})$ and, Velo $(473 \mathrm{~mm})$. Although a decreasing rainfall trend was identified at all stations, was statistically significant in a few cases only. Previous investigations that focused on the spatial and temporal distribution of the precipitation in Greece found a substantial decreasing trend due to general changes in the atmospheric circulation patterns over the Balkan Peninsula (Amanatidis et al., 1992; Fidas et al., 2004).

Using multiple linear regression (Kutiel, 1987; Naum and Tsanis, 2004; Voudouris et al., 2006) between mean annual rainfall and geographical parameters of each station, the annual rainfall distribution follows the equation:

$P=13114-223 \lambda-201 \phi+0.32 h$

where: $P$ is the station mean annual rainfall $(\mathrm{mm}) ; \lambda$ and $\phi$ are the longitude and latitude of the station (degrees), respectively; and $h$ is the altitude of the station (m). A decrease of mean annual rainfall of about $2.5 \mathrm{~mm}$ for every $1 \mathrm{~km}$ movement eastward and a decrease of about $2 \mathrm{~mm}$ for every $1 \mathrm{~km}$ movement northward was found. In addition, the mean annual rainfall increases by $32 \mathrm{~mm}$ per $100 \mathrm{~m}$ of ground elevation.

Equation (3) was spatially implemented in Fig. 3 with the use of the raster calculator of ArcView GIS, the Digital Elevation Model (DEM), and the spatial longitudes and latitudes of the prefecture in WGS84 geographic projection system (datum). The analysis was accomplished on the basis of a raster grid with spatial resolution of $20 \mathrm{~m}$. The isohyetal map in Fig. 3 is the outcome of this procedure.

The long term mean annual rainfall is $1.39 \times 10^{9} \mathrm{~m}^{3} / \mathrm{yr}(\mathrm{Ta}-$ ble 3). The largest precipitation amounts occur in the SW

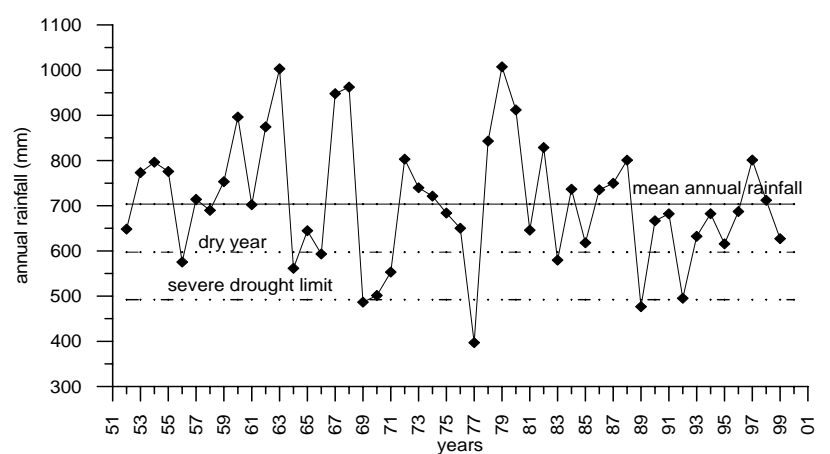

Figure 4. Annual rainfall fluctuation in Psari station (period 19512000).

part of the region and decrease towards the eastern and northern coastal parts of the prefecture. The unequal distribution of precipitation results in water surplus in the western fraction of the study area and water deficit in the eastern.

The first rainfall of a hydrological year in the lowlands occurs in middle September or later. The highest precipitation depths, on monthly basis, occur in November or December in the majority of the stations (15) and only in two of them in January; the lowest occur in July.

\subsection{Extreme rainfall events}

Extreme climatic events (droughts and floods) occurred during the last decades. Figure 4 depicts the annual rainfall fluctuation at Psari station. A decrease in rainfall depth over $30 \%$, when compared to the mean value, is observed in 1969 , 
Table 2. Geological formations and coefficient of infiltration.

\begin{tabular}{lccc}
\hline Geological formations & Coefficient of infiltration $(\%)$ & Area $\left(\mathrm{km}^{2}\right)$ & Percentage $(\%)$ \\
\hline Carbonate rocks of Tripolis zone & 52 & 140.2 & 6.19 \\
Limestone of Sub-Pelagonian zone & 52 & 309.2 & 13.67 \\
Limestone of Pindos zone & 47 & 133.8 & 5.91 \\
Marly limestone & 30 & 3.9 & 0.17 \\
Recent beach deposits and sands & 21 & 66.7 & 2.95 \\
Alluvial deposits & 18 & 212 & 9.36 \\
Fluvial terraces and scree & 18 & 194.3 & 8.58 \\
Plio-Pleistocene conglomerates & 14 & 318 & 14.04 \\
Marine and near shore deposits of Tyrrhenian, red clayey sand & 12 & 253.4 & 11.19 \\
Flysch & 7 & 35.1 & 1.45 \\
Metamorphic rocks of Zarouchla serie & 7 & 34.7 & 1.53 \\
Schists & 5 & 36.3 & 1.60 \\
Ophiolites & 5 & 53.6 & 2.37 \\
Radiolarites of Pindos zone & 5 & 1.4 & 0.06 \\
Marls of Pleistocene & 3 & 468.9 & 20.71 \\
Volcano rocks & 3 & 2.9 & 0.13 \\
\hline
\end{tabular}

Table 3. Hydrological balance in the watersheds of Korinthia prefecture as are shown in Fig. 3.

\begin{tabular}{|c|c|c|c|c|c|c|c|c|c|c|c|c|}
\hline & \multirow[t]{2}{*}{ Watershed } & \multirow{2}{*}{$\begin{array}{c}\text { Area } \\
\left(\mathrm{km}^{2}\right)\end{array}$} & \multicolumn{4}{|c|}{ Precipitation } & \multicolumn{4}{|c|}{ Evapotranspiration } & \multirow{2}{*}{$\begin{array}{c}\text { Infiltration } \\
\text { Volume } \\
\left(10^{6} \mathrm{~m}^{3}\right)\end{array}$} & \multirow{2}{*}{$\begin{array}{l}\text { Runoff } \\
\text { Volume } \\
\left(10^{6} \mathrm{~m}^{3}\right)\end{array}$} \\
\hline & & & $\min$ & $\max$ & mean & $\begin{array}{c}\text { Volume } \\
\left(10^{6} \mathrm{~m}^{3}\right)\end{array}$ & $\min$ & $\max$ & mean & $\begin{array}{l}\text { Volume } \\
\left(10^{6} \mathrm{~m}^{3}\right)\end{array}$ & & \\
\hline 1 & Rachiani & 203.4 & 379.6 & 769.5 & 502.9 & 102.3 & 279.0 & 356.3 & 325.0 & 66.1 & 13.9 & 22.3 \\
\hline 2 & Zapandis & 136.0 & 399.8 & 697.0 & 516.0 & 70.2 & 293.6 & 358.6 & 331.5 & 45.0 & 5.7 & 19.4 \\
\hline 3 & Elisson & 33.6 & 400.8 & 827.4 & 583.5 & 19.6 & 294.0 & 343.5 & 326.9 & 11.0 & 2.0 & 6.6 \\
\hline 4 & Sythas & 180.5 & 414.3 & 1.243 .4 & 744.1 & 134.3 & 11.3 & 362.5 & 303.4 & 54.7 & 30.6 & 48.9 \\
\hline 5 & Fonissa & 54.6 & 421.7 & 958.9 & 686.5 & 37.5 & 251.7 & 356.8 & 337.1 & 18.4 & 3.6 & 15.4 \\
\hline 6 & Stymfalia & 218.9 & 675.6 & 1.216 .5 & 802.7 & 175.7 & 46.1 & 385.6 & 333.5 & 73.0 & 45.6 & 57.0 \\
\hline 7 & Skoupeikos & 71.7 & 424.5 & 1.023 .5 & 628.2 & 45.0 & 200.6 & 355.5 & 332.0 & 23.8 & 9.4 & 11.8 \\
\hline 8 & Olvios (Feneos) & 237.5 & 749.2 & 1.247 .0 & 879.6 & 208.9 & 7.5 & 393.1 & 323.8 & 76.9 & 52.0 & 79.9 \\
\hline 9 & Dervenios & 61.0 & 447.9 & 1.024 .0 & 680.9 & 41.5 & 200.6 & 362.0 & 338.0 & 20.6 & 5.3 & 15.6 \\
\hline 10 & Asopos & 279.6 & 398.2 & 1.009 .8 & 625.9 & 175.0 & 247.9 & 378.7 & 353.4 & 98.8 & 34.4 & 41.8 \\
\hline 11 & Potamias & 168.2 & 366.7 & 767.8 & 533.3 & 89.7 & 269.7 & 339.8 & 316.6 & 53.3 & 22.6 & 13.8 \\
\hline 12 & Examilia coastal area & 37.5 & 364.0 & 561.0 & 405.6 & 15.2 & 267.0 & 319.0 & 284.6 & 10.7 & 2.2 & 2.3 \\
\hline 13 & Arachnaio coastal area & 101.5 & 347.4 & 676.5 & 487.5 & 49.5 & 255.5 & 317.8 & 298.4 & 30.3 & 18.0 & 1.2 \\
\hline 14 & Sofiko coastal area & 27.6 & 351.0 & 612.7 & 434.6 & 12.0 & 258.1 & 312.9 & 287.5 & 7.9 & 3.7 & 0.3 \\
\hline 15 & Fournias & 64.8 & 378.1 & 685.3 & 537.5 & 34.8 & 276.5 & 325.8 & 312.6 & 20.2 & 11.7 & 2.8 \\
\hline 16 & Xerias & 19.8 & 376.2 & 634.8 & 485.9 & 9.6 & 276.5 & 318.3 & 303.2 & 6.0 & 2.9 & 0.6 \\
\hline 17 & Kyrillou & 13.8 & 406.8 & 642.5 & 508.5 & 7.0 & 296.7 & 341.3 & 324.4 & 4.4 & 0.6 & 1.9 \\
\hline 18 & Seliandros & 30.1 & 394.4 & 748.6 & 574.6 & 17.3 & 292.8 & 341.2 & 327.2 & 9.8 & 1.8 & 5.6 \\
\hline 19 & Melissi coastal area & 10.1 & 403.0 & 547.2 & 445.7 & 4.5 & 296.2 & 333.9 & 311.4 & 3.1 & 0.5 & 0.8 \\
\hline 20 & Katharoneri & 14.6 & 410.2 & 688.1 & 495.9 & 7.2 & 301.6 & 342.3 & 322.9 & 4.7 & 0.8 & 1.7 \\
\hline 21 & Agiorgitiko & 17.6 & 408.8 & 727.3 & 533.7 & 9.4 & 300.7 & 340.8 & 328.0 & 5.8 & 0.8 & 2.8 \\
\hline 22 & Loutraki coastal area & 212.4 & 325.1 & 739.1 & 451.4 & 95.9 & 236.9 & 300.2 & 278.3 & 59.0 & 17.2 & 19.6 \\
\hline \multirow[t]{2}{*}{23} & Gerania coastal area & 69.3 & 311.4 & 674.5 & 429.6 & 29.8 & 229.0 & 296.1 & 271.3 & 18.8 & 5.3 & 5.6 \\
\hline & Total & 2264 & & & & 1390 & & & & 722.3 & 290.6 & 377.7 \\
\hline
\end{tabular}

1977, 1989, 1992 and 2000. Droughts present a random occurrence with duration, most of the times, of one or two years (Voudouris et al., 2002). Prolonged drought periods, which lead to increased groundwater pumping, cause groundwater level decline as well as a deficient groundwater balance in the main aquifer system of the prefecture. Droughts also contribute to a quality deterioration of surface water as a result of a decline in stream discharge (Lambrakis et al., 1997; Sreedevi, 2002). 


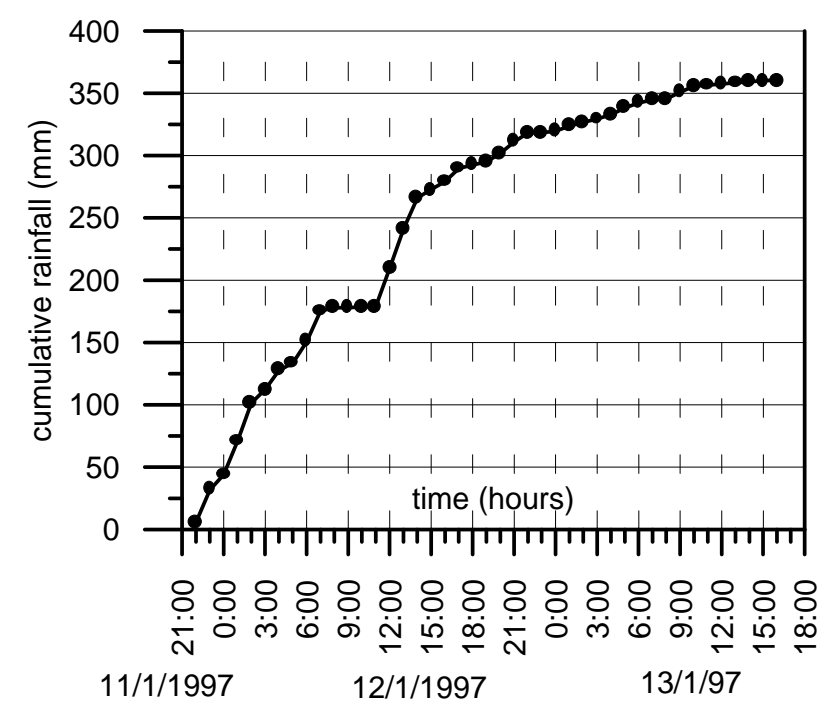

Figure 5. Cumulative rainfall curve between the 11 and 13 January 1997.

Rainfall events in the study area often take the form of heavy storms, with destructive effects. Such a storm, that caused extended damage in the city of Korinthos, occurred on the 12 January 1997 (Voudouris and Papadopoulos, 1998). According to the data collected from the rain gauge station of Velo (Fig. 5), the abovementioned incident lasted $42.6 \mathrm{~h}$ (started on 11 January at 21:00 and ended on 13 January at 15:40). The total rainfall depth in a 12 -h period was $180 \mathrm{~mm}$, whilst in a 24-h period it was $301.8 \mathrm{~mm}$ with a maximum intensity of $31.5 \mathrm{~mm} / \mathrm{h}$. The total rainfall depth of this event measured up to $64 \%$ of the mean annual rainfall. However, extreme rainfall events are not alone responsible for the devastating floods in the area. Human interventions along the stream banks, the deforestation, the deficient maintenance of the sewerage system, the rapid urbanization of the area in the absence of rural planning and the poor and incomplete road constructions have played a key role in the destructive flood of the 12 January 1997.

\subsection{Evapotranspiration}

Potential evapotranspiration was calculated from mean monthly temperature. Based on Thornthwaite method (Voudouris, 2006), the estimated actual evapotranspiration is $74 \%-81 \%$ of the annual rainfall amounts in lowlands and $38-50.5 \%$ in mountainous area. A rather strong negative association $(E r=-0.043 h+81.8, r=0.84)$, was found between the actual evapotranspiration $\operatorname{Er}(\%)$ and the altitude $h(\mathrm{~m})$ for each station (Fig. 6).

As for precipitation, the DEM of the prefecture with the use of the above-mentioned equation was used to derive the spatial distribution of Er through the use of the raster calculator of ArcGIS. For the calculations, the field capacity or

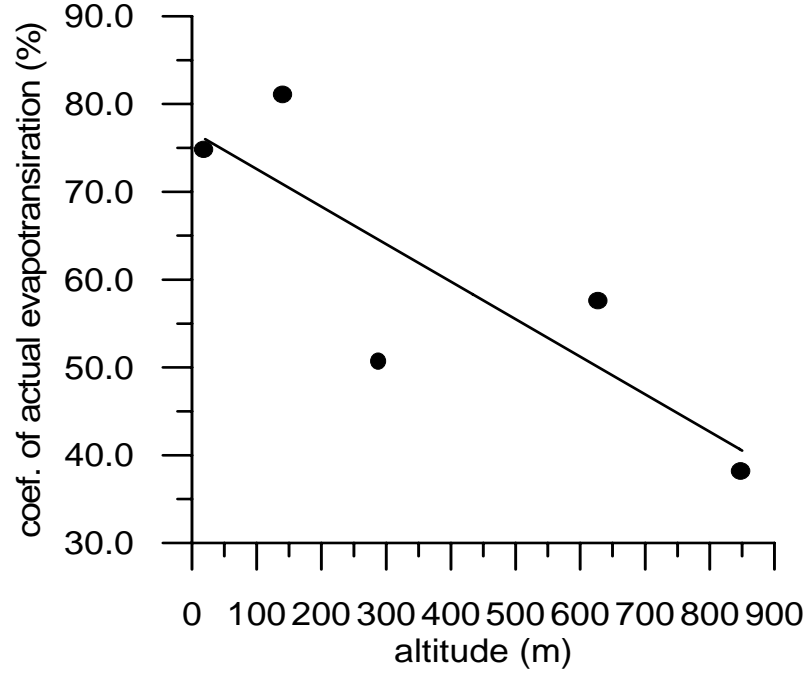

Figure 6. Coefficient of actual evapotranspiration (\%) vs altitude (m).

water holding capacity was set at $110 \mathrm{~mm}$ for post-alpines deposits and $60 \mathrm{~mm}$ for limestone. The total volume was estimated to be $722.3 \times 10^{6} \mathrm{~m}^{3} / \mathrm{yr}$ ( $52 \%$ of the annual rainfall). The remaining amount between rainfall and evapotranspiration is allocated to infiltration and surface runoff (streamflow).

The mean water balance shows a water surplus from January to April, while in May-June the process of consumption of soil humidity takes place. Water deficit is observed from June to October, while the period October-December is the replenishment period (Fig. 7).

\subsection{Infiltration}

Infiltration coefficients of similar formations in Greece were adopted for the geological formations in Table 2. The spatial distribution of the infiltration coefficients derived from the product of the raster of infiltration coefficients to the raster of annual precipitation amounts. Based on these coefficients and geological map of the prefecture (Fig. 2) which was digitised in vector polygon form, the total infiltration was estimated to be $290.6 \times 10^{6} \mathrm{~m}^{3} / \mathrm{yr}$ or $20.9 \%$ of the annual precipitation. The analysis was accomplished on the basis of a raster grid with a cell size of $50 \mathrm{~m} \times 50 \mathrm{~m}$.

The major aquifers in the prefecture of Korinthos occur within the carbonate rocks (karst aquifers), due to their high infiltration capacity (45-52\% of the annual rainfall) (Rockel and Hotzl, 1986). Karst aquifer systems often discharge groundwater through large springs; inland freshwater springs and coastal brackish water springs. The mean annual volume of spring freshwater was estimated to be $117.5 \times 10^{6} \mathrm{~m}^{3} / \mathrm{yr}$ (Voudouris, 2007). 


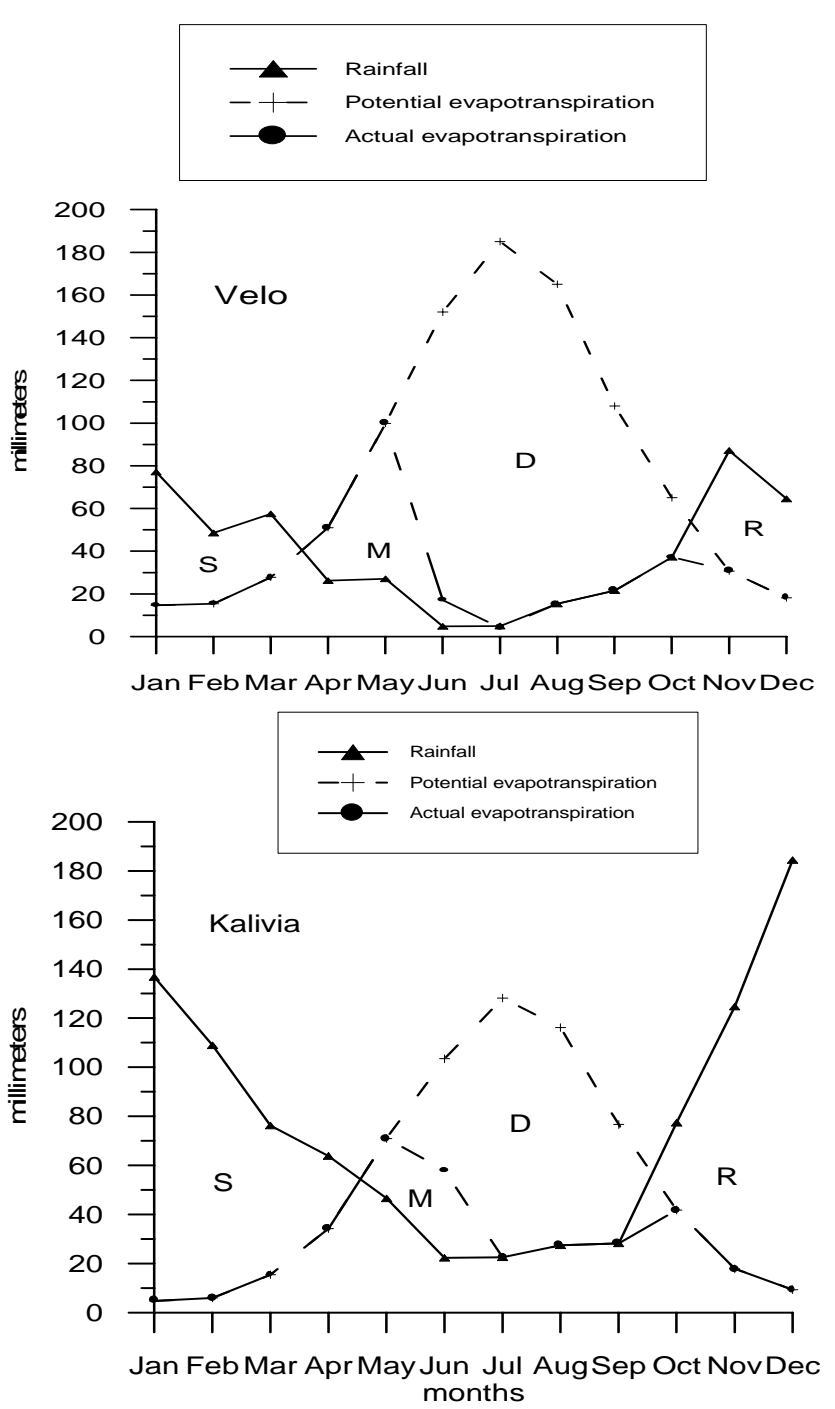

Figure 7. Hydrological water balance. ( $\mathrm{S}=$ water surplus, $\mathrm{M}=$ soil moisture use, $\mathrm{D}$ = water deficit, $\mathrm{R}$ = replenishment period).

\subsection{Streamflow}

Flow in the torrents persists throughout the wet period, depending on the amounts of rainfalls and snowfalls. There are not available data for the other torrents of the prefecture.

The spatial distribution of surface runoff derived when the respective raster of equivalent infiltration coefficients and $E r$ subtracted from the respective mean rainfall depths. Based on Thornthwaite approach, the mean annual streamflow $(R)$ was estimated to be $377.7 \times 10^{6} \mathrm{~m}^{3}$ or $27.1 \%$ of the mean annual rainfall (Table 3). The water balance parameters for each hydrological watershed are shown in Table 3.

According to the Ministry of Environment Land Planning and Public Works an average of $30 \times 10^{6}-64 \times 10^{6} \mathrm{~m}^{3} / \mathrm{yr}$ of water discharges from the Asopos basin $\left(284 \mathrm{~km}^{2}\right)$ by sur- face runoff. A small amount $\left(14 \times 10^{6} \mathrm{~m}^{3} / \mathrm{yr}\right)$ of surface runoff of Asopos river is captured for irrigation use and the major part of winter time torrential flow goes to the sea (Voudouris, 2006).

\section{Conclusions}

Multiple linear regression and GIS were used to estimate the spatial distribution of rainfall. The physiography of the Korinthia area controls the annual rainfall distribution. The largest precipitation amounts occur in the SW part of the region and decrease towards east and north. Extreme climatic events in the form of both droughts and floods have been occured.

With regards to the hydrologic balance components of the studied prefecture on temporal and annual basis, using the Thornthwaite method and GIS technique the following conclusions can be drawn: (i) the long term rainfall is $1.39 \times 10^{9} \mathrm{~m}^{3} / \mathrm{yr}$, (ii) the mean actual evapotranspiration amounts $0.72 \times 10^{9} \mathrm{~m}^{3} / \mathrm{yr}$ and (iii) the infiltration and streamflow were estimated to be $0.29 \times 10^{9} \mathrm{~m}^{3} / \mathrm{yr}$ and $0.37 \times 10^{9} \mathrm{~m}^{3} / \mathrm{yr}$, on average, respectively. On spatial basis, the hydrologic balance identified the highest surplus in western part of the area and the lowest in the eastern.

The hydrological balance could be useful in order to optimize the water resources management in a basin scale, according to Water Framework Directive 2000/60/EC. Future investigations of the hydrological balance would benefit by improvement in hydrological data monitoring, application of isotopic analysis and computer modelling to simulate water cycle.

Edited by: M. Brilly

Reviewed by: M. Brilly

\section{References}

Amanatidis, G., Reparis, X., Paliatsos, A., Bartzis, I.: The spatial distribution of the precipitation trend in Greece, Proc. of the Congress of the Greek Committee for Water Resources Management (in Greek), 225-233, 1992.

Fidas, H., Noulopoulou, Ch. Makrogiannis, T., and Bora-Senta, E.: Trend analysis of precipitation time series in Greece and their relationship with atmospheric circulation: 1955-2001. Proc. 7th Geographical Congress, Mytilini, Greece (in Greek), I, 106-113, 2004.

Kutiel, H.: Rainfall variations in the Galilee (Israel). I. Variations in the spatial distribution in the periods 1931-60 and 1951-80, J. Hydrol., 94, 331-344, 1987.

Lambrakis, N., Voudouris, K., Tiniakos, L., and Kallergis, G.: Impacts of drought and overpumping on the quaternary aquifers of the Glafkos basin (Patras region, W. Greece), Environ. Geol., 29, 209-216, 1997.

Linsley, R., Kohler, M., and Paulhus, J.: Hydrology for engineers, McGraw-Hill Book Company, 492 pp., 1988. 
Macheras, P. and Kolyva-Machera, F.: Temporal and spatial characteristics of annual precipitation over the Balkans in the 20th century, Int. J. Climatol., 10, 495-504, 1990.

Maidment, D. R.: GIS and hydrologic modelling. Environmental modelling with GIS, Oxford University Press, New York, 1993.

Mitchell, J., Dzerdzeevskii, B., Flohn, H., Hofmeyer, W., Lamb, H., Rao, K., and Wallen, C.: Climatic change, WMO, Technical Note, No. 79, World Meteorological Organisation, Geneva, 79 pp., 1966.

Naoum, S. and Tsanis, I. K.: Orographic precipitation modeling with multiple linear regression, J. Hydrol. Eng., 9, 79-102, 2004.

Nikolaou, N., Koukis, G., and Lambrakis, N.: Rainfall and landslide manifestation correlation in Korinthos County, Greece, Proceedings of the Conference on Engineering Geology and the Environment, Greece, 919-924, Balkema, 1997.

Panagopoulos, A., Voudouris, K., Hionidi, M., and Koumantakis, J.: Irrational water resources management impacts on the coastal aquifer system of Korinthia, Proc. of International Conference "Restoration and Protection of the Environment V", July 2002, Skiathos, I, 419-426, 2002.

Rockel, T. and Hotzl, H.: Karst Hydrogeology of the Central and Eastern Peloponnesus, 5th Int. Symposium on under ground water tracing, Athens, edited by: Morfis, A. and Zojer, H., 127-152, 1986.

Ross, M. A. and Tara, P. D.: Integrated hydrologic modelling with GIS, J. Water Resour. Plan. Manage., 119(2), 129-140, 1993.
Sreedevi, P. D.: Climatic water balance and droughts of Pageru river basin, Cuddapah district, Andhra Pradesh, Environ. Geol., 42, 681-689, 2002.

Voudouris, K. and Papadopoulos, K.: Quantitative analysis of heavy rainfall (Jan. 12; 1997) in Korinthos region, B. Geol. Soc. Greece (in Greek), XXXII, 4, 33-41, 1998.

Voudouris, K., Hionidi, M., Panagopoulos, A., and Koumantakis, I.: Extreme climatic events in the prefecture of Korinthos (Greece) and their impact on groundwater resources, Proc. 5th International Conference "Water resources management in the era of transition", Athens, 4-8 September 2002, 107-114, 2002.

Voudouris, K. and Antonakos, A.: Rainfall distribution in Korinthia prefecture, Geographies, Exantas (in Greek), 4, 53-61, 2003.

Voudouris, K.: Groundwater Balance and Safe Yield of the coastal aquifer system in NEastern Korinthia, Greece, Appl. Geogr., 26, 291-311, 2006.

Voudouris, K., Mavrommatis, Th., Daskalaki, P., and Soulios, G.: Rainfall variations in Crete island (Greece) and their impacts on water resources. Publicaciones del Instituto Geologico y Minero de España. Serie: Hidrogeologia y aguas subterráneas No 18, Karst, climate change and groundwater, Madrid, 453-463, 2006.

Voudouris, K.: An application of SWOT analysis and GIS for the optimization of water resources management in Korinthia prefecture, Greece. Proc. European Water Resources Association, Chania, Crete-Greece, 14-16 June, 307-315, 2007. 